\title{
Study on Genetic Variability, Correlation and Path Coefficient Analysis for Yield and Component Traits in Greengram
}

\author{
P. Narmada Varma*, B. Baisakh and D. Swain \\ Department of Plant Breeding and Genetics, College of Agriculture, Orissa University of \\ Agriculture and Technology, Bhubaneswar-751003, Odisha, India \\ *Corresponding author
}

\section{A B S T R A C T}

\begin{tabular}{|l|}
\hline K e y w o r d s \\
Genetic variability, \\
Correlation, Path \\
coefficient analysis
\end{tabular}

Keywords

Genetic variability, coefficient analysis

Article Info

Accepted:

10 October 2018
Genetic variability is the prime objective for crop improvement fraternity. Higher the amount of variation for a character greater will be the scope of its improvement through selection. Fifty six genotypes of greengram were evaluated in RBD for estimation of genetic variability, heritability, genetic advance, correlation coefficient and path coefficient analysis for yield and component traits. The genotypes showed wide and highly significant variation in all these traits. Seed yield of the genotype varied from 1.8 to 6.1 $\mathrm{g} /$ plant. PCV and GCV estimates were high for primary branches per plant. Plant height, pods per plant, days to $50 \%$ flowering, and maturity had high heritability with high genetic advance which indicated additive gene effect. Correlation studies indicated that plant height, clusters per plant, pods per plant, pod length, and 100 seed weight showed positive correlation with yield. Pods per plant had highest direct positive effect on yield followed by 100 seed weight.

\section{Introduction}

Pulses are important component of human diet as a source of protein. On an average, pulses contain $20-25 \%$ of protein in dry seeds, which is about 2.5-3.0 times that of cereals. Greengram is one of the important pulse crops in Asia particularly India and South-East Asia.

India is the largest producer of greengram in the world and accounts for $65 \%$ area (second after China) and $54 \%$ production (Pratap et al., 2013). Most of the production in India is traded and consumed locally, whereas Thailand is the world's largest exporter of greengram.
In India greengram is the third major pulse crop followed by chickpea and pigeonpea. It occupies 3.55 million hectares of area with a production of 1.5 million tons. In India, major greengram producing states are Andhra Pradesh, Odisha, Maharastra, Madhya Pradesh, Rajasthan, Bihar and Tamil Nadu.

In Odisha, greengram ranks first in terms of both area and production amongst the pulse crops. In Odisha, greengram is cultivated in an area of 833.11 thousand ha with a production of 396.93 thousand ton and productivity of $476 \mathrm{~kg} / \mathrm{ha}$ (OAS, 2013-14) and being cultivated in Ganjam, Kalahandi, Bolangir, Bargarh, Nayagarh, Cuttack, Nuapada. 
Though the estimated pulse requirement in Odisha by 2020 is focused to be 49.4 lakh ton the present productivity is very low to achieve the target. The low productivity may be due to sowing on marginal and sub-marginal land under residual moisture in rice fallows, lack of high yielding genotypes. All these factors either independently or jointly result in the poor productivity of this crop.

Research on greengram was started in 1925 at Pusa. But systematic and well organized research for development of high yielding, disease/ insect-pest resistant varieties and production technology was started with the establishment of All India Coordinated Pulse Improvement Programme (AICPIP) in 1967 which was later on bifurcated into three groups later in i.e. AICRP on Chickpea, AICRP on MULLaRP (Mungbean, Urdbean, Lentil, Lathyrus, Rajmash and Pea), AICRP on Pigeonpea, Under the aegis of AICRP, more than 100 varieties of greengram have been released so far cultivation in different agro-ecological regions and seasons. Despite the systematic and continuous breeding efforts through conventional breeding method, substantial genetic gain in production and productivity of these two crops could not be achieved.

Thus the present study was undertaken in greengram to evaluate the yield and yield attributing traits and study the nature and extent of variability for different traits and to find out the correlation among different traits and direct and indirect effects of component traits on seed yield.

\section{Materials and Methods}

The field experiment was conducted at the EB-II Section in the department of Plant Breeding and Genetics, College of Agriculture, OUAT, Bhubaneswar during Rabi season of 2014-15.The material comprised of 56 genotypes of green gram including selections from local varieties (7), selections from crosses (15), selections from mutants (7) and selections from breeding lines (27). The field experiment was conducted in a randomized block design (RBD) in 3 replications with 56 entries. The trail was sown on 20.10.2014 and irrigated on the same day. Each genotype was represented in five rows with a spacing of $30 \mathrm{~cm} \mathrm{X} 10 \mathrm{~cm}$. Fertilizers were applied @ 20:40:20 kg of $\mathrm{N}: \mathrm{P}_{2} \mathrm{O}_{5}: \mathrm{K}_{2} \mathrm{O}$ with 300 cft. of farm yard manure (FYM) per hectare. All the FYM, Phosphatic, Potassic and half of the nitrogenous fertilizers were applied as basal dose and rest half of the nitrogenous fertilizers were applied at 21 days after sowing. Hoeing and hand weeding were done at the time of top dressing. Observations on ten quantitative traits viz., days to $50 \%$ flowering, days to maturity, plant height, primary branches per plant, clusters per plant, pods per plant, pod length, seeds per pod, test weight and yield per plant were recorded. Out of the 10 quantitative traits, days to $50 \%$ flowering and maturity were recorded on the plot basis and for the rest of eight characters, the observations were recorded on ten randomly selected competitive plants per plot in each replication and average was calculated. Mean values were computed and data was analysed for analysis of variance and coefficient of variance as suggested by Al-Jibouri(1958), heritability and genetic advance by Johnson (1953), genotypic and phenotypic correlation coefficients and path coefficient analysis were estimated adopting the procedure suggested by Dewey and $\mathrm{Lu}(1959)$.

\section{Results and Discussion}

The variance (mean square values) between genotypes for 10 characters are presented in the Table 1. The data revealed the existence of significant difference among the genotypes for the characters studied. 
Genetic variability, heritability and genetic advance in quantitative traits of greengram

A significant variability ranging from 31.33 days to 38.6 days was noticed with respect to days to $50 \%$ flowering. Days to maturity ranged from 61 to 70 days. Moderately significant variability ranging from $30.66 \mathrm{~cm}$ to $53.00 \mathrm{~cm}$ was noticed with respect to plant height. Primary branches per plant ranged from 0.00 to 2.73 branches.

A medium range of variation was observed in case of number of clusters per plant from 2.00 to 6.66. Pods per plant showed wide range of variability from 9.00 to 19.66 . Pod length varied from 5.00 to $10.00 \mathrm{~cm}$. A moderate range of variation was observed in case of seeds per pod 9.00 to 12.66 . A wide variability ranging from 2.13 to $4.68 \mathrm{gm}$ was recorded for seed weight. Yield per plant recorded 1.82 to $6.16 \mathrm{gm}$ significant amount of variability.

The co-efficient of variation with respect to different characters are presented in Table 2 which ranged from 0.65 to 19.28 . The traits like primary branches per plant, clusters per plant and pods per plant showed high variability.

On the contrary, the traits like plant height, pod length, seeds per pod, 100 seed weight and yield per plant showed moderate variability. The traits like days to $50 \%$ flowering, days to maturity and exhibited low variability. The genotypic variance ranged from 2.91 for days to maturity to 48.38 for primary branches per plant.

The phenotypic variance ranged from 3.02 for days to maturity to 54.05 for primary branches per plant. Heritability (broad sense) estimates ranged from the lowest for seeds per pod to highest for 100 seed weight. The genetic advance was lowest for seeds per pod and highest for plant height.

\section{Character association}

The phenotypic $\left(\mathrm{r}_{\mathrm{p}}\right)$ and genotypic correlation $\left(\mathrm{r}_{\mathrm{g}}\right)$ indicated in Table 3 was lowest between days to $50 \%$ flowering and 100 seed weight to the highest between days to $50 \%$ flowering and maturity. Yield per plant was positively and significantly associated with traits like pods per plant, 100 seed weight, clusters/ plant Plant height, seeds per pod, pod length showed positive correlation with yield. But yield was negatively correlated with branches, maturity, and days to $50 \%$ flowering.

Days to $50 \%$ flowering was positively and significantly correlated with days to maturity, primary branches, plant height but was negatively correlated with 100 seed weight, yield per plant, pod length, seed per pod, pods/ plant and cluster/ plant. Days to maturity was positively correlated with primary branches per plant and negatively correlated with clusters per plant, plant height, pods per plant, seeds per pod, yield per plant, 100 seed weight and pod length. Plant height was positively and significantly correlated with all traits except for pod length which showed negative correlation.

Cluster per plant was positively and significantly correlated with traits except for seeds per pod and pod length. Primary branches per plant was positively correlated with pods per plant and negatively correlated with yield per plant, seeds per pod, pod length and 100 seed weight. Pods per plant were positively and significantly correlated with yield per plant and 100 seed weight and negatively correlated with seeds per pod and pod length. Pod length was positively and significantly correlated with seeds per pod, 100 seed weight and yield per plant. Seeds per pod were positively correlated with yield per plant and negatively correlated with 100 seed weight. 100 seed weight was positively and significantly correlated with yield per plant. 
Table.1 Analysis of variance for ten characters in greengram

\begin{tabular}{|c|c|c|c|c|c|c|}
\hline Sl. No. & Character & Source & d.f & S.S & M.S & F value \\
\hline \multirow[t]{3}{*}{1} & \multirow{3}{*}{$\begin{array}{l}\text { Days to } 50 \% \\
\text { flowering }\end{array}$} & Replication & 2 & 5.57 & 2.78 & $10.08 * *$ \\
\hline & & Genotype & 55 & 565.95 & 10.29 & $37.20 * *$ \\
\hline & & Error & 110 & 30.42 & 0.27 & \\
\hline \multirow[t]{3}{*}{2} & \multirow[t]{3}{*}{ Days to maturity } & Replication & 2 & 1.17 & 0.58 & 2.24 \\
\hline & & Genotype & 55 & 582.25 & 10.58 & $40.40^{* *}$ \\
\hline & & Error & 110 & 28.82 & 0.26 & \\
\hline \multirow[t]{3}{*}{3} & \multirow[t]{3}{*}{ Plant height } & Replication & 2 & 36.99 & 18.49 & 1.94 \\
\hline & & Genotype & 55 & 4773.32 & 86.78 & $9.10 * *$ \\
\hline & & Error & 110 & 1048.33 & 9.53 & \\
\hline \multirow[t]{3}{*}{4} & \multirow{3}{*}{$\begin{array}{l}\text { Clusters } \\
\text { Per plant }\end{array}$} & Replication & 2 & 1.79 & 0.89 & 2.27 \\
\hline & & Genotype & 55 & 120.51 & 2.19 & $5.53 * *$ \\
\hline & & Error & 110 & 43.53 & 0.39 & \\
\hline \multirow[t]{3}{*}{5} & \multirow{3}{*}{$\begin{array}{l}\text { Primary branches } \\
\text { Per Plant }\end{array}$} & Replication & 2 & 0.11 & 0.05 & 0.53 \\
\hline & & Genotype & 55 & 76.21 & 1.38 & $13.08 * *$ \\
\hline & & Error & 110 & 11.64 & 0.10 & \\
\hline \multirow[t]{3}{*}{6} & \multirow[t]{3}{*}{ Pods per plant } & Replication & 2 & 0.14 & 0.07 & 0.04 \\
\hline & & Genotype & 55 & 1095.31 & 19.91 & $13.10^{* *}$ \\
\hline & & Error & 110 & 167.18 & 1.51 & \\
\hline \multirow[t]{3}{*}{7} & \multirow[t]{3}{*}{ Pod length } & Replication & 2 & 0.51 & 0.25 & 0.72 \\
\hline & & Genotype & 55 & 181.51 & 3.30 & $9.35 * *$ \\
\hline & & Error & 110 & 38.82 & 0.35 & \\
\hline \multirow[t]{3}{*}{8} & \multirow[t]{3}{*}{ Seeds per pod } & Replication & 2 & 0.58 & 0.29 & 0.64 \\
\hline & & Genotype & 55 & 107.61 & 1.95 & $4.35 * *$ \\
\hline & & Error & 110 & 49.41 & 0.44 & \\
\hline \multirow[t]{3}{*}{9} & \multirow[t]{3}{*}{100 seed weight } & Replication & 2 & 0.00 & 0.00 & 0.06 \\
\hline & & Genotype & 55 & 59.53 & 1.08 & $42.95 * *$ \\
\hline & & Error & 110 & 2.77 & 0.02 & \\
\hline \multirow[t]{3}{*}{10} & \multirow[t]{3}{*}{ Yield per plant } & Replication & 2 & 0.06 & 0.03 & 0.12 \\
\hline & & Genotype & 55 & 130.54 & 2.37 & $9.74 * *$ \\
\hline & & Error & 110 & 26.79 & 0.24 & \\
\hline
\end{tabular}

Table. 2 Genetic parameters of 10 characters in 56 greengram genotypes

\begin{tabular}{|l|c|c|c|c|c|c|c|c|}
\hline \multicolumn{1}{|c|}{ Character } & Mean & Range & $\begin{array}{c}\text { CV } \\
(\%)\end{array}$ & $\begin{array}{c}\text { GCV } \\
(\%)\end{array}$ & $\begin{array}{c}\text { PCV } \\
(\%)\end{array}$ & $\begin{array}{c}\mathbf{h}^{2} \\
(\%)\end{array}$ & $\begin{array}{c}\text { GA }(\% \text { of } \\
\text { mean })\end{array}$ \\
\hline Days to 50\% flowering & 34.76 & $31.33-38.66$ & 1.23 & 5.25 & 5.46 & 92.00 & 3.61 & $\mathbf{1 0 . 4 0}$ \\
\hline Days to maturity & 63.64 & $61.00-70.00$ & 0.65 & 2.91 & 3.02 & 92.00 & 3.67 & 5.78 \\
\hline Plant height(cm) & 41.58 & $30.66-53.00$ & 6.06 & 12.20 & 14.28 & 72.00 & 8.92 & 21.47 \\
\hline Cluster per plant & 4.38 & $2.00-6.66$ & 11.60 & 17.63 & 22.72 & 60.00 & 1.23 & $\mathbf{2 8 . 1 8}$ \\
\hline Primary branches/plan t & 1.35 & $0.00-2.73$ & 19.20 & 48.38 & 54.05 & 80.00 & 1.20 & $\mathbf{8 9 . 2 1}$ \\
\hline Pods per plant & 14.32 & $9.00-19.66$ & 11.20 & 17.29 & 19.31 & 80.00 & 4.56 & 31.88 \\
\hline Pod length & 6.63 & $5.00-10.00$ & 7.31 & 14.93 & 17.41 & 73.00 & 1.74 & 26.38 \\
\hline seeds per pod & 11.04 & $9.00-12.66$ & 5.10 & 6.41 & 8.83 & 52.00 & 1.05 & $\mathbf{9 . 6 0}$ \\
\hline 100 seed weight & 3.29 & $2.13-4.68$ & 3.90 & 18.04 & 18.68 & 93.00 & 1.18 & 35.91 \\
\hline Yield per plant & 3.94 & $\mathbf{1 . 8 2 - 6 . 1 6}$ & $\mathbf{1 0 . 2 0}$ & 21.37 & $\mathbf{2 4 . 7 7}$ & $\mathbf{7 4 . 0 0}$ & $\mathbf{1 . 4 9}$ & $\mathbf{3 7 . 9 9}$ \\
\hline
\end{tabular}


Table.3 Phenotypic correlation $\left(r_{p}\right)$ and genotypic correlation $\left(r_{g}\right)$ among the 10 characters in 56 greengram genotypes

\begin{tabular}{|c|c|c|c|c|c|c|c|c|c|c|}
\hline Character & & $\begin{array}{l}\text { Days to } \\
\text { maturity }\end{array}$ & $\begin{array}{l}\text { Plant } \\
\text { height }\end{array}$ & $\begin{array}{l}\text { Clusters/ } \\
\text { plant }\end{array}$ & $\begin{array}{c}\text { Primary } \\
\text { branches/ } \\
\text { Plant }\end{array}$ & Pods/plant & $\begin{array}{c}\text { Pod } \\
\text { length }\end{array}$ & Seeds / pod & $\begin{array}{l}100 \text { seed } \\
\text { weight }\end{array}$ & $\begin{array}{l}\text { Yield/ } \\
\text { plant }\end{array}$ \\
\hline \multirow{2}{*}{$\begin{array}{l}\text { Days to } 50 \% \\
\text { flowering }\end{array}$} & $\mathrm{rp}$ & $0.772 * *$ & 0.023 & -0.080 & $0.292 *$ & -0.180 & -0.318 & -0.199 & -0.397 & -0.380 \\
\hline & rg & $0.838^{* *}$ & 0.064 & -0.128 & $0.356^{*}$ & -0.221 & -0.382 & -0.282 & -0.433 & -0.467 \\
\hline \multirow{2}{*}{$\begin{array}{l}\text { Days to } \\
\text { maturity }\end{array}$} & $\mathrm{rp}$ & & -0.061 & -0.047 & 0.176 & -0.116 & -0.305 & -0.288 & -0.303 & -0.300 \\
\hline & rg & & -0.059 & -0.086 & 0.204 & -0.147 & -0.361 & -0.386 & -0.318 & -0.367 \\
\hline \multirow{2}{*}{$\begin{array}{l}\text { Plant } \\
\text { height }(\mathrm{cm})\end{array}$} & $\mathrm{rp}$ & & & $0.373^{* *}$ & 0.158 & 0.139 & -0.014 & 0.200 & 0.161 & 0.206 \\
\hline & rg & & & $0.509 * *$ & 0.232 & 0.172 & -0.096 & 0.141 & 0.191 & 0.248 \\
\hline \multirow{2}{*}{$\begin{array}{l}\text { Clusters/ } \\
\text { plant }\end{array}$} & $\mathrm{rp}$ & & & & 0.180 & $0.571 * *$ & -0.133 & -0.085 & 0.177 & $0.490 * *$ \\
\hline & rg & & & & 0.249 & $0.656 * *$ & -0.154 & -0.103 & 0.221 & $0.613 * *$ \\
\hline \multirow{2}{*}{$\begin{array}{l}\text { Primary } \\
\text { branches/ } \\
\text { Plant } \\
\end{array}$} & $\mathrm{rp}$ & & & & & 0.166 & -0.128 & -0.123 & -0.294 & -0.052 \\
\hline & rg & & & & & 0.148 & -0.248 & -0.218 & -0.346 & -0.152 \\
\hline \multirow[t]{2}{*}{ Pods/plant } & $\mathrm{rp}$ & & & & & & -0.158 & -0.093 & 0.010 & $0.699 * *$ \\
\hline & $\mathrm{rg}$ & & & & & & -0.223 & -0.189 & 0.004 & $0.706 * *$ \\
\hline \multirow[t]{2}{*}{ Pod length } & $\mathrm{rp}$ & & & & & & & $0.432 * *$ & 0.235 & 0.079 \\
\hline & rg & & & & & & & $0.562 * *$ & $0.271^{*}$ & 0.068 \\
\hline \multirow[t]{2}{*}{ Seeds/ pod } & $\mathrm{rp}$ & & & & & & & & -0.017 & 0.121 \\
\hline & $\mathrm{rg}$ & & & & & & & & -0.030 & -0.038 \\
\hline \multirow{2}{*}{$\begin{array}{l}100 \text { seed } \\
\text { weight }\end{array}$} & $\mathrm{rp}$ & & & & & & & & & $0.577 * *$ \\
\hline & rg & & & & & & & & & $0.639 * *$ \\
\hline
\end{tabular}


Table.4 Direct (diagonal and bold) and indirect effects of 9 component traits on seed yield in 56 greengram genotypes

\begin{tabular}{|c|c|c|c|c|c|c|c|c|c|}
\hline Character & $\begin{array}{l}\text { Days to } 50 \% \\
\text { flowering }\end{array}$ & $\begin{array}{l}\text { Days to } \\
\text { maturity }\end{array}$ & $\begin{array}{c}\text { Plant } \\
\text { height } \\
(\mathrm{cm})\end{array}$ & $\begin{array}{l}\text { Clusters/ } \\
\text { plant }\end{array}$ & $\begin{array}{l}\text { Primary } \\
\text { branches } \\
\text { /plant }\end{array}$ & pods/plant & $\begin{array}{l}\text { Pod } \\
\text { length }\end{array}$ & Seeds/ pod & $\begin{array}{l}100 \text { seed } \\
\text { weight }\end{array}$ \\
\hline $\begin{array}{l}\text { Days to } \mathbf{5 0 \%} \\
\text { flowering }\end{array}$ & 0.075 & -0.061 & -0.002 & -0.006 & -0.008 & -0.156 & 0.007 & -0.035 & -0.278 \\
\hline Days to maturity & 0.062 & -0.073 & 0.002 & -0.004 & -0.005 & -0.103 & 0.007 & -0.048 & -0.204 \\
\hline Plant height $(\mathrm{cm})$ & 0.004 & 0.004 & -0.043 & 0.024 & -0.005 & 0.121 & 0.001 & 0.017 & 0.122 \\
\hline Clusters/plant & -0.009 & 0.006 & -0.022 & 0.047 & -0.006 & 0.464 & 0.003 & -0.012 & 0.142 \\
\hline $\begin{array}{l}\text { Primary } \\
\text { branches/plant }\end{array}$ & 0.026 & -0.014 & -0.010 & 0.011 & -0.024 & 0.104 & 0.004 & -0.027 & -0.222 \\
\hline Pods /plant & -0.016 & 0.010 & -0.007 & 0.030 & -0.003 & 0.708 & 0.004 & -0.023 & 0.002 \\
\hline Pod length & -0.028 & 0.026 & 0.004 & -0.007 & 0.006 & -0.158 & -0.019 & 0.070 & 0.174 \\
\hline Seeds / pod & -0.021 & 0.028 & -0.006 & -0.004 & 0.005 & -0.133 & -0.010 & 0.124 & -0.019 \\
\hline 100 seed weight & -0.032 & 0.023 & -0.008 & 0.010 & 0.008 & 0.002 & -0.005 & -0.003 & 0.643 \\
\hline
\end{tabular}




\section{Path co-efficient analysis}

The phenotypic correlation co-efficient of seed yield with the 9 component traits were partitioned into direct and indirect effects of component traits on yield by path co-efficient analysis shown in Table 4. Pods per plant had the highest direct positive effect on yield. The characters 100 seed weight and seeds per pod had the moderate positive direct effect on yield. Days to flowering, Clusters per plant, showed negligible direct effect on seed yield. Pod length, primary branches, plant height and days to maturity, showed the negative direct effect on seed yield. Highest positive indirect effect was contributed by pods per plant and 100 seed weight via clusters per plant followed by pod length via test weight and100 seed weight and pods per plant via plant height respectively on seed yield. Negative indirect effect was contributed by days to $50 \%$ flowering on seed yield via plant height, and clusters per plant followed by clusters per plant via 50\% flowering and primary branches. Also the negative indirect effect of seeds per pod on seed yield per plant was counteracted by clusters per plant, plant height.

Genetic variability is the prime objective for crop improvement fraternity. Higher the amount of variation for a character greater will be the scope of its improvement through selection. Correlation analysis provides the information on nature and magnitude of the association of different components characters with seed yield, which is regarded as highly complex trait in which the breeder is ultimately interested. So it is a matter of great importance to the plant breeders to find out as to which of the characters are correlated with yield and also how they are associated among themselves. PCV and GCV were higher for primary branches per plant, yield per plant, clusters per plant, pods per plant and 100 seed weight. It is in close agreement with Narasimhulu et al., (2013), Garje et al., (2014), Degefa et al., (2014). It was observed that branches per plant exhibited maximum difference between PCV and GCV which indicate the higher environmental influence on this character. While selecting this character, much care should be taken up. Estimation of heritability along with genetic gain is usually more useful in predicting the resultant effect for selecting the best individual. Primary branches, pods per plant, days to maturity and days to $50 \%$ flowering had moderate to high heritability accompanied with high genetic advance indicating additive gene effect. Characters like 100 -seed weight and yield per plant with high to moderate heritability but low genetic advance indicated non additive gene effects.

Considering $r_{p}$ and $r_{g}$ of the component traits with yield it was observed that yield per plant was significantly and positively correlated with pods per plant, 100 seed weight clusters per plant, plant height, pod length and seeds per pod both phenotypically and genotypically except for seed per pod which showed negative correlation genotypically. Earlier similar findings have been reported by Kumar et al., (2013), Garje et al., (2014). Yield is negatively correlated with days to $50 \%$ flowering, days to maturity and primary branches which were earlier reported by Mishra et al., (2014). If negative association between characters is due to pleiotropic effects it would be very difficult to obtain the desired combinations while if linkage is involved, special breeding programmes are needed to break these linkage blocks. Knowledge of the correlations that exist between important characters may be helpful in the choice of good genotypes for any crop improvement programme.

Path analysis is the standardized partial regression coefficient, which splits the correlation coefficient into the measures of direct and indirect effects of a set of independent variables on the dependent variable. Pods per plant had the highest direct positive effect on yield which was earlier reported by Mishra et al., (2014), Garje et al., (2014) and Sahu et al., (2014). The characters 100 seed weight and seeds per pod had the moderate positive direct effect on yield which has been confirmed earlier by Thippani et al., 
(2013), and Lalinial et al., (2014). If the correlation between yield and character is due to the direct effects of character, it reflects true relationship between them, selection can be practiced for such a character in order to improve yield. If correlation is due to indirect effect of the character through another component trait, the breeder has to select for the latter trait through which indirect effect is exerted. Pod length, primary branches, plant height and days to maturity showed the negative direct effect on seed yield. The result of negative direct effect indicated that these characters had low association and selection based on these characters would not be effective.

\section{References}

Al-Jibouri, H. A., Miller, P. A. and Robinson, H.F. 1958. Genotypic and environmental variances and co-variances in upland cotton crosses of interspecific origin. Agronomy Journal 50: 633-636.

Degefa, I., Petros, Y. and Andargie, M. 2014. Genetic variability, heritability and genetic advance in mung bean (Vigna radiata L. Wilczek) Accessions, Plant Science Today, 1(2): 94-98.

Dewey, O. R. and Lu, K. H. 1959. A correlation and path coefficient analysis of components of crested wheat grass seed production. Journal of Agronomy 57: 515-518.

Garje, U. A., Bhailume, M. S., Nagawade, D. R. and Parhe, S. D. 2014. Short communication genetic association and path coefficient analysis in green gram [Vigna radiata L. Wilczek], Journal of Food Legumes, 27(2): 151-154.

Johnson, H. W., Robinson, H. F. and Comstock, R. E. 1955. Estimates of genetic and environmental variability in soybean. Agronomy Journal 47: 314-318.

Kumar, K., Prasad, Y., Mishra, S. B., Pandey, S. S. and Kumar, R. 2013. Study on genetic variability, correlation and path analysis with grain yield and yield attributing traits in green gram [Vigna radiata (L.) Wilczek]. The Bioscan. 8(4): 1551-1555.

Lalinia, A. A. and Khameneh, M. M. 2014. Multivariate statistical method for determining interrelationships among seed yield and related characters in mung bean, International Journal of Farming and Allied Sciences 274-281.

Mishra, A., Mohanty, S. K., Mishra, S., Samal, K. C. and Das, S. 2014. Character association and genetic diversity in rainfed greengram [Vigna radiata L Wilczek], Indian Journal of Dryland Agriculture Research and Development 29(1): 45-51.

Narasimhulu, R., Naidu, N.V., Reddy, K.H.P., Rajan, C.P.D. and Naidu, M.G. 2014. Association analysis among yield attributes in greengram (Vigna radiata L. Wilczek) Bioinfolet 11 (4 a): 1021 - 1025.

Pratap, A., Gupta, D.S., Singh, B.B. and Kumar, S. 2013. Development of super early genotypes in greengram [Vigna radiata L. Wilczek], Legume Research 36 (2): 105 110.

Sahu, H., Amadabade, J., Kumar, P., Sao, A. and Patel, R.P. 2014. Assessment of segregating generations for genetic variability and yield regulating traits in mungbean. The Bioscan, 9(4): 1701-1706.

Thippani, S., Eswari, K.B. and Rao, M.V.B. 2013. Character association between seed yield and its components in green gram (Vigna radiata L. Wilczek), International Journal of Applied Biology and Pharmaceutical technology 4(4)

\section{How to cite this article:}

Narmada Varma, P., B. Baisakh and Swain, D. 2018. Study on Genetic Variability, Correlation and Path Coefficient Analysis for Yield and Component Traits in Greengram. Int.J.Curr.Microbiol.App.Sci. 7(10): 3429-3436. doi: https://doi.org/10.20546/ijcmas.2018.710.398 